\title{
Ethical Challenges of Nurses in COVID- 19 Pandemic: Integrative Review
}

\author{
Gdiom Gebreheat (iD) \\ Hirut Teame ${ }^{2}$ \\ 'Department of Nursing, College of \\ Medicine and Health Sciences, Adigrat \\ University, Adigrat, Ethiopia; \\ ${ }^{2}$ Department of Public Health, College of \\ Medicine and Health Sciences, Adigrat \\ University, Adigrat, Ethiopia
}

\begin{abstract}
Currently, nurses are in the middle of the battle against COVID-19. The pandemic situation has put these professionals against various ethical challenges. Therefore, this review aims to identify the main ethical challenges faced by nurses during COVID-19 pandemic. This integrative review was guided by the Preferred Reporting Items of Systematic Reviews and Meta-Analysis Protocols. All English version studies that reported ethical challenges of nurses during the COVID-19 pandemic, from November 9, 2019, to November 9, 2020, were eligible for the review. The electronic databases used were PubMed, Google Scholar, JURN, Cochrane Library E-Journals, MEDLINE, Academic Search Complete, CINAHL. Accordingly, 8 articles were included for further analysis and synthesis. The ethical challenges of nurses were categorized into three thematic areas: nurses' safety, role and moral distress, resource allocation, and client-nurse relationship. Thus, the lack of full protection of nurses across the health industry has raised ethical questions such as the extent of their duty, scarce resources, and the failure of personal protective equipment. In connection, a significant number of nurses were also facing moral distress because of prolonged pressure to maintain the resources needed to provide safe and high-quality nursing care. Furthermore, nurses were challenged to restrict many COVID-19 patients from having end-of-life communication with their families. Overall, nurses are still facing various ethical challenges across the globe. Therefore, it is important to mobilize resources and invest in nurses to bring long-lasting solutions.
\end{abstract}

Keywords: COVID-19, nursing ethics, ethical issues

\section{Introduction}

COVID-19 pandemic has changed the image of our world with its circular impact on health, living tradition, economy, and politics. In particular, the tradition of the health industry has changed dramatically because of the unpredictable nature of the pandemic. Since the breakout of COVID-19, health care providers have faced multidimensional challenges in carrying out their professional duties and responsibilities. Studies have shown that frontline health professionals are challenged by a lack of pandemic preparedness, scarcity of clinical supplies, and implementation of social distancing. ${ }^{1,2}$

Amid the pandemic, health professionals were challenged to apply the four main principles of biomedical ethics in taking care of the clients, ie autonomy, justice, beneficence, and non-maleficence. For instance, health workers who assigned on duty without personal protective equipment were at high risk of infection not only to themselves but also to their families and other clients. Thus, it violates "no harm to others" or "non-maleficence" ethical principle. ${ }^{3}$
Correspondence: Gdiom Gebreheat Department of Nursing, College of Medicine and Health Sciences, Adigrat University, P.o.box 50

Tel +25 I9l402770 I

Email gdiom.gebreheat@adu.edu.et 
Nurses are amongst the frontline health professionals in the health care setting, especially in taking care of COVID-19 patients. They were also actively involved in hospital leadership and management activities, such as in mobilizing hospital resources for the pandemic. Therefore, it is obvious that they are facing a lot of ethical challenges and difficulties as they are usually under the pressure of workloads. According to Turale et al, nurses have faced unpalatable and complex ethical challenges in practice, with moral conflicts, high levels of patient deaths, and long working hours. ${ }^{4}$

However, limited data are available on the ethical challenges that nurse professionals are facing through this time of global health crisis, ie COVID-19 pandemic. Therefore, this review will identify the ethical challenges of nurses during the COVID-19 pandemic.

\section{Materials and Methods Design}

An integrative review approach was adopted. ${ }^{5}$ This study was conducted according to the Preferred Reporting Items of Systematic Reviews and Meta-Analysis Protocols (PRISMA-P) checklist guidelines. ${ }^{6}$

\section{Search Strategy}

The electronic databases searched were PubMed, Google Scholar, JURN, Cochrane Library E-Journals, MEDLINE, Academic Search Complete, CINAHL. Available resources were accessed through the University of Algarve EBSCO database. In addition, articles were also searched through a review of the grey literature available on local university shelves, and institutional repositories, and by reviewing the reference lists of already identified articles. Electronic database searches were conducted from November 1, 2020 to November 13, 2020.

The key terms used for the database searches were: "((((ethical issues) OR (ethical challenges)) OR (ethical barriers)) AND (nurse*)) AND (COVID-19 pandemic)". These search terms were pre-defined to allow a comprehensive search strategy that included all fields within records and Medical Subject Headings (MeSH terms), to expand the search in an advanced PubMed search. An advanced PubMed search was run using the predefined search terms to allow a comprehensive and detailed search strategy. We combined keywords with the "OR" operator and then linked the search strategies for the two axes with the "AND" operator to search for studies.

\section{Inclusion and Exclusion Criteria}

All the studies that reported ethical challenges of nurses' during the COVID-19-pandemic from November 9, 2019 to November 9, 2020 were eligible for inclusion in the review. However, studies in languages other than English were excluded. Documents that were inaccessible after three email contacts with the principal investigator were also excluded. The eligibility criteria for each article were checked and decided on the consensus of two independent authors.

\section{Data Collection}

\section{Selection of Studies}

All database-search results were sent/exported to Mendeley reference manager software version 1.19.4. After putting all the search results in a single folder, duplicated articles were removed. Next, two independent reviewers screened the studies according to the preset inclusion criteria. Through title screening, the articles that clearly mentioned ethical issues, challenges, and/or barriers of nurses in COVID-19 were selected for abstract screening. Then, articles that fulfilled the eligibility criteria, based on their titles and abstracts, were retrieved for full-text screening. Eventually, fully eligible articles were selected for further analysis. The inclusion of articles was considered in the consensus of the reviewers (Figure 1).

\section{Data Items}

The primary outcome of this review was the ethical challenges faced by nurses during the COVID-19 pandemic. We have classified them into three main themes of ethical challenges. The first category was focused on the main ethical issues of nurses' safety, role, and moral distress. Second, the ethical challenges faced by nurse professionals on resources allocation and, third, the ethical aspects of the nurse-client relationship during the COVID-19 pandemic.

\section{Data Extraction and Analysis}

Data were extracted using an excel table. We extracted variables that were related to the ethical challenges of nurses during COVID-19 pandemic. Therefore, we recorded the study setting, author, year, aim/research question, and methods used in each article. Using content analysis technique, the ethical challenges of nurses were categorized into three areas, namely, nurses' safety, role and moral distress, resource allocation, and the nurse-client relationship. 


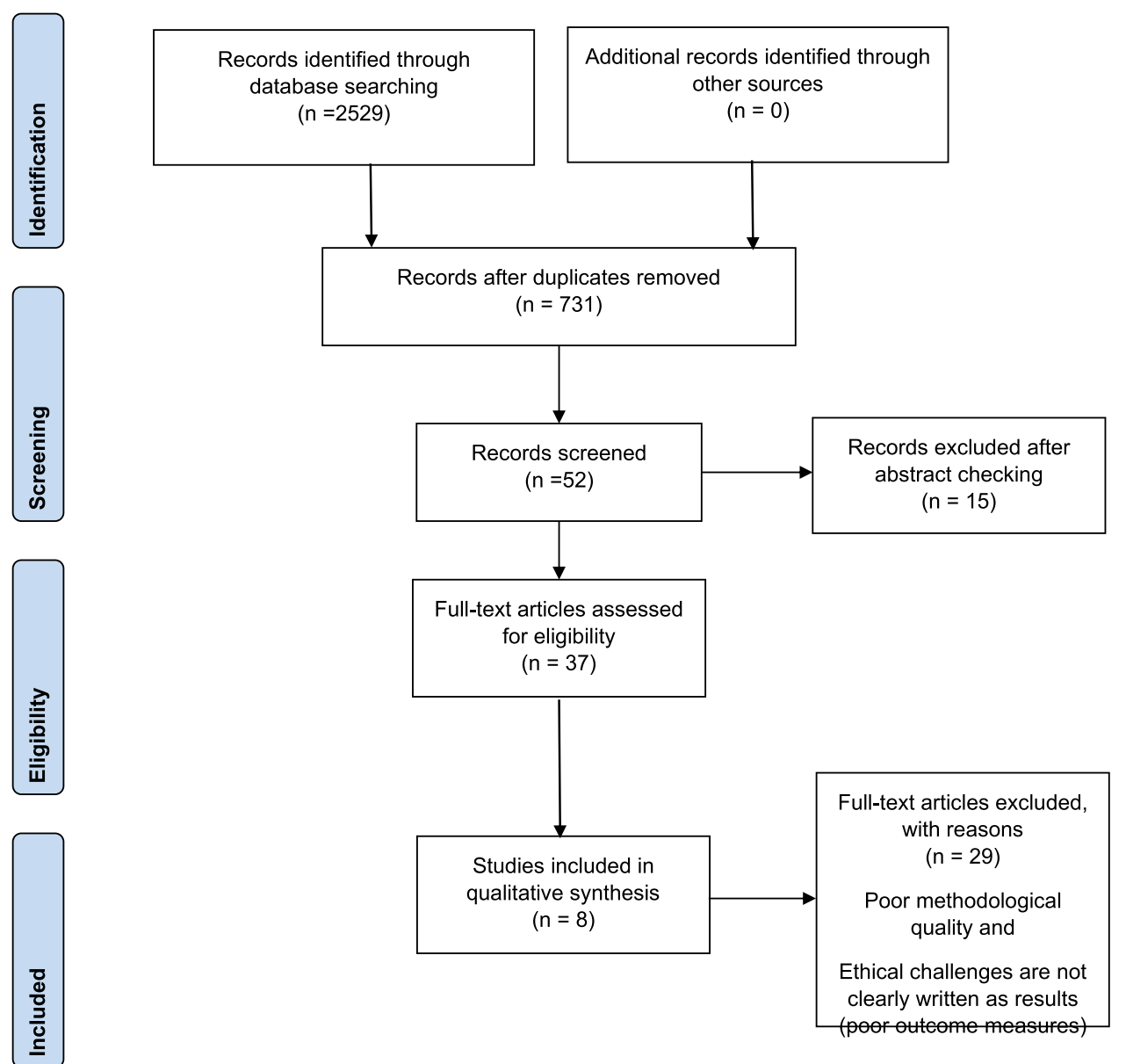

Figure I PRISMA flow diagram showing study selection process. Adapted from Moher D, Liberati A, Tetzlaff J, Altman DG, The PRISMA Group (2009). Preferred Reporting Items for Systematic Reviews and Meta-Analyses: The PRISMA Statement. PLoS Med 6(7): el $000097 .{ }^{6}$

\section{Quality Assessment}

The methodological quality of the included articles was evaluated using the quality appraisal tools from the Joanna Briggs Institute (JBI) 2020, namely the JBI quality appraisal checklists for analytical cross-sectional studies, the JBI quality appraisal checklists for text and opinion papers, and the JBI quality appraisal checklists for qualitative research.

\section{Results}

\section{Characteristics of the Studies}

The initial search for articles generated 2529 articles, of which 8 articles fit the inclusion and exclusion criteria set in this integrative review for further analysis and synthesis. Of these, seven articles ${ }^{4,7-12}$ has focused on the ethical issues of nurses working in hospitals while the remaining one ${ }^{13}$ have discussed school nurses' ethical concerns. Six articles ${ }^{4,7-10,13}$ were discussion papers of authors whereas one was conducted in qualitative approach, ${ }^{12}$ and the other was employed in descriptive correlation design. ${ }^{11}$ The maximum sample size among the included articles was 231 registered nurses (Table 1). ${ }^{11}$

\section{Quality Appraisal of the Review}

The JBI quality appraisal tools were used based on the consensus of two reviewers. We have included studies with explicitly stated objectives, clear source of opinion, pre-set eligibility criteria for inclusion in the sample, a detailed description of settings, reliable and valid measurement of exposure, and appropriate statistical analysis. Based on the consensus of reviewers, articles were classified into high, moderate, and low methodological quality. Accordingly, the one and only qualitative articles were scored $9 / 10$ and classified as high-quality $(8-10 / 10)$. The six opinion articles were also classified as high quality (5-6/6). The remaining, descriptive correlation study was 
Table I Characteristics and Summary of the Articles Included in the Review

\begin{tabular}{|c|c|c|c|c|c|c|c|}
\hline \multirow{2}{*}{$\begin{array}{l}\text { Author, } \\
\text { Year, } \\
\text { Country }\end{array}$} & \multirow[t]{2}{*}{ Title } & \multirow{2}{*}{$\begin{array}{l}\text { Aim/Research } \\
\text { Questions }\end{array}$} & \multicolumn{3}{|c|}{ Methods } & \multirow[t]{2}{*}{ Main Findings } & \multirow{2}{*}{$\begin{array}{l}\text { Critical } \\
\text { Appraisal }\end{array}$} \\
\hline & & & Setting & Design & $\begin{array}{l}\text { Sample } \\
\text { Size }\end{array}$ & & \\
\hline $\begin{array}{l}\text { (Combe, } \\
2020) \\
N^{13}\end{array}$ & $\begin{array}{l}\text { Reopening } \\
\text { Schools During } \\
\text { COVID-19 }\end{array}$ & $\begin{array}{l}\text { To investigate school } \\
\text { nurse ethical conflicts } \\
\text { and moral dilemmas }\end{array}$ & $\begin{array}{l}\text { School } \\
\text { nurses }\end{array}$ & Opinion & NA & $\begin{array}{l}\text { - School nurses are facing } \\
\text { with ethical decisions } \\
\text { and are experiencing } \\
\text { moral distress. }\end{array}$ & $6 / 6$ \\
\hline $\begin{array}{l}\text { (McKenna, } \\
2020) \\
\mathrm{NA}^{10}\end{array}$ & $\begin{array}{l}\text { Covid-19: } \\
\text { Ethical issues for } \\
\text { nurses }\end{array}$ & $\begin{array}{l}\text { To identify the ethical } \\
\text { issues for nurses in } \\
\text { COVID-19 }\end{array}$ & $\begin{array}{l}\text { Hospital } \\
\text { nurses }\end{array}$ & Opinion & NA & $\begin{array}{l}\text { The justice - ensuring } \\
\text { equity and fairness in } \\
\text { how patients were } \\
\text { treated. } \\
\text { - Insufficient intensive } \\
\text { care beds and ventila- } \\
\text { tors for the predicted } \\
\text { number of COVID-19 } \\
\text { victims. }\end{array}$ & $6 / 6$ \\
\hline $\begin{array}{l}\text { (Turale } \\
\text { et al, } \\
2020 \text { ), } \\
\text { USA and } \\
\text { Australia }{ }^{4}\end{array}$ & $\begin{array}{l}\text { Challenging } \\
\text { times: ethics, } \\
\text { nursing, and the } \\
\text { COVID-19 } \\
\text { pandemic }\end{array}$ & $\begin{array}{l}\text { To discuss aspects of } \\
\text { COVID-19 pandemic to } \\
\text { the ethical values of } \\
\text { nurses }\end{array}$ & $\begin{array}{l}\text { Hospital } \\
\text { nurses }\end{array}$ & Opinion & NA & $\begin{array}{l}\text { - They were posed unpa- } \\
\text { latable and complex } \\
\text { ethical issues in practice, } \\
\text { with moral conflicts, } \\
\text { high levels of acuity and } \\
\text { patient deaths, and long } \\
\text { working hours. }\end{array}$ & $6 / 6$ \\
\hline $\begin{array}{l}\text { (Morley } \\
\text { et al, } \\
2020) \text {, } \\
\mathrm{NA}^{9}\end{array}$ & $\begin{array}{l}\text { Covid-19: } \\
\text { Ethical } \\
\text { Challenges for } \\
\text { Nurses }\end{array}$ & $\begin{array}{l}\text { To discuss three } \\
\text { overarching nurses' } \\
\text { ethical issues in COVID- } \\
19\end{array}$ & $\begin{array}{l}\text { Hospital } \\
\text { nurses }\end{array}$ & Opinion & NA & $\begin{array}{l}\text { - The safety of nurses, } \\
\text { patients, colleagues, and } \\
\text { families. } \\
\text { - The allocation of scarce } \\
\text { resources. }\end{array}$ & $6 / 6$ \\
\hline $\begin{array}{l}\text { (Nasser } \\
\text { et al, } \\
2020) \text {, } \\
\text { Palestine }^{8}\end{array}$ & $\begin{array}{l}\text { Ethical issues in } \\
\text { caring for } \\
\text { COVID-patients: } \\
\text { A view from } \\
\text { Gaza }\end{array}$ & $\begin{array}{l}\text { To discuss the ethical } \\
\text { issues of nurses in caring } \\
\text { for COVID-19 patients }\end{array}$ & $\begin{array}{l}\text { Hospital } \\
\text { nurses }\end{array}$ & Opinion & NA & $\begin{array}{l}\text { - Injustice in patient treat- } \\
\text { ment and resource } \\
\text { allocation. }\end{array}$ & $5 / 6$ \\
\hline $\begin{array}{l}\text { (Zhu et al, } \\
\text { 2020), } \\
\text { China }^{7}\end{array}$ & $\begin{array}{l}\text { The ethics of } \\
\text { refusing to care } \\
\text { for patients } \\
\text { during the } \\
\text { coronavirus } \\
\text { pandemic: } \\
\text { A Chinese } \\
\text { perspective }\end{array}$ & $\begin{array}{l}\text { To examine ethical } \\
\text { decisions of health } \\
\text { professionals in COVID- } \\
19 \text { pandemic }\end{array}$ & $\begin{array}{l}\text { Hospital } \\
\text { nurses }\end{array}$ & Opinion & NA & $\begin{array}{l}\text { The bioethical principles } \\
\text { of autonomy, justice, } \\
\text { beneficence, and non- } \\
\text { maleficence. } \\
\text { - Challenges on public } \\
\text { health ethics and nur- } \\
\text { sing guides to justify } \\
\text { their decisions as to } \\
\text { whether they are } \\
\text { entitled to refuse to } \\
\text { treat COVID-19 } \\
\text { patients. }\end{array}$ & $6 / 6$ \\
\hline
\end{tabular}


Table I (Continued).

\begin{tabular}{|c|c|c|c|c|c|c|c|}
\hline \multirow{2}{*}{$\begin{array}{l}\text { Author, } \\
\text { Year, } \\
\text { Country }\end{array}$} & \multirow[t]{2}{*}{ Title } & \multirow{2}{*}{$\begin{array}{l}\text { Aim/Research } \\
\text { Questions }\end{array}$} & \multicolumn{3}{|c|}{ Methods } & \multirow[t]{2}{*}{ Main Findings } & \multirow{2}{*}{$\begin{array}{l}\text { Critical } \\
\text { Appraisal }\end{array}$} \\
\hline & & & Setting & Design & $\begin{array}{l}\text { Sample } \\
\text { Size }\end{array}$ & & \\
\hline $\begin{array}{l}\text { (Sperling, } \\
2020), \\
\text { Israel }^{11}\end{array}$ & $\begin{array}{l}\text { Ethical } \\
\text { dilemmas, } \\
\text { perceived risk, } \\
\text { and motivation } \\
\text { among nurses } \\
\text { during the } \\
\text { COVID-19 } \\
\text { pandemic }\end{array}$ & $\begin{array}{l}\text { The study examined how } \\
\text { Israeli nurses respond to } \\
\text { ethical dilemmas and } \\
\text { tension during the } \\
\text { COVID-19 outbreak, and } \\
\text { to what extent this is } \\
\text { associated with their } \\
\text { perceived risk and } \\
\text { motivation to provide } \\
\text { care? }\end{array}$ & $\begin{array}{l}\text { Hospital } \\
\text { nurses }\end{array}$ & $\begin{array}{l}\text { Descriptive } \\
\text { correlational } \\
\text { study }\end{array}$ & $\begin{array}{l}231 \\
\text { registered }\end{array}$ & $\begin{array}{l}\text { - Around } 25 \% \text { of nurses } \\
\text { believe they have the } \\
\text { right to refuse to treat } \\
\text { certain patients during } \\
\text { the COVID-19 } \\
\text { outbreak. } \\
\text { - } 81.4 \% \text { of nurses believed } \\
\text { that all patients have the } \\
\text { right to equal and opti- } \\
\text { mal treatment. } \\
47.2 \% \text { of nurses think } \\
\text { that older patients } \\
\text { should be connected to } \\
\text { respirators. }\end{array}$ & $7 / 8$ \\
\hline $\begin{array}{l}\text { (Jia et al, } \\
2020), \\
\text { China }^{12}\end{array}$ & $\begin{array}{l}\text { Nurses' ethical } \\
\text { challenges caring } \\
\text { for people with } \\
\text { COVID-19: } \\
\text { A qualitative } \\
\text { study }\end{array}$ & $\begin{array}{l}\text { To examine the ethical } \\
\text { challenges encountered } \\
\text { by nurses caring for } \\
\text { patients with the novel } \\
\text { coronavirus pneumonia } \\
\text { (COVID-19) and to } \\
\text { provide nurses with } \\
\text { suggestions and support } \\
\text { regarding promotion of } \\
\text { their mental health. }\end{array}$ & $\begin{array}{l}\text { Hospital } \\
\text { nurses }\end{array}$ & $\begin{array}{l}\text { Qualitative } \\
\text { study }\end{array}$ & 18 nurses & $\begin{array}{l}\text { - Neglected patient rights. } \\
\text { - Unequal exposure to } \\
\text { the infectious } \\
\text { environment. } \\
\text { - Role ambiguity. } \\
\text { - Insufficient response to } \\
\text { urgency. } \\
\text { - Low sense of } \\
\text { responsibility. } \\
\text { - Lack of knowledge and } \\
\text { skills. }\end{array}$ & $9 / 10$ \\
\hline
\end{tabular}

also, similarly, scored $7 / 8$ and lied within the range of high-quality paper (7-8/8).

\section{Ethical Challenges of Nurses in COVID-19 Pandemic}

A total of 8 articles have reported the ethical challenges faced by nurses during the COVID-19 pandemic. After a full reading and conceptual understanding of the articles included in the review, a content analysis was carried out to figure out the ethical challenges of nurses during the pandemic. Accordingly, the ethical challenges of nurses were categorized into three areas, namely, nurses' safety, role and moral distress, resource allocation, and the nurseclient relationship.

\section{Theme I: Nurses' Safety, Role, and Moral Distress} Under this theme, we have included five articles. Accordingly, in the fight against COVID-19, the safety of nurses is a pressing ethical issue, as they were asked to work under circumstances that put them at risk to their overall health and well-being. The lack of full protection for nurses across the health industry raises ethical questions about the extent of their duty, lack of personal protective equipment, and risk of failure of personal protective equipment. ${ }^{7,9,12}$ Significant numbers of nurses were also experiencing moral distress because they were under prolonged pressure to maintain the resources needed to provide safe and high-quality nursing care. ${ }^{4,8}$ Nurses were also subjected to run various roles in case such a question was raised, which duty belongs to whom. ${ }^{12}$

\section{Theme 2: Resource Allocation}

Another decision demanding concern is the fair allocation of scarce resources. Based on the findings from six articles, different views have been given on how resource allocation was an ethical issue during the outbreak. Health resources are limited, from the very beginning, let alone in COVID-19 pandemic. For this reason, emergency 
nurses are usually engaged in prioritizing patients. They are passing through blurred decisions on issues, such as which patients are most likely to get into a scarce intensive care unit bed, mechanical ventilation, or extracorporeal membrane oxygenation. Similarly, the issue of scarce personnel protective equipment for nurses is another burning ethical topic as stated by different authors. ${ }^{4,8-11,13}$

\section{Theme 3: Nurse-Client Relationship}

Six articles have focused on the ethical challenges of the triangular relationship of nurse-patient and family relationship. COVID-19 has also put the client-centred approach in question, which brings another ethical and professional crisis. During the pandemic, many people are dying in isolation and ICU separated from their families and even without getting the opportunities to have end-oflife-conversations. Unfortunately, families were also quarantined if they had any contact with the dying person. ${ }^{8,9}$ During the pandemic, in USA and Australia, some private hospital nurses were out of duty. ${ }^{4}$ Jia et al have also mentioned some ethical challenges including insufficient response to urgency requirements of the situation. Also, interviewees reported that some staff worked slowly while rescuing patients and delivering other nursing activities that reflected a low sense of moral responsibility. ${ }^{12}$

\section{Discussion}

The devastating COVID-19 pandemic that has suffered the worldwide population resulted in an unprecedented admission of patients in ICU, sharpen ethical dilemma, and suffer of health-care professionals.

These elements are liable to shake up the ethical nursing principles and consequently raise ethical challenges for health professionals and, in our issue, nurses. ${ }^{14,15}$ To date, there are four basic principles of biomedical ethics in clinical practice: autonomy, justice, beneficence and nonmaleficence. ${ }^{16}$ However, these basic biomedical ethical principles and other ethical guidelines used previously in managing infectious disease outbreaks do not fully apply to the current COVID-19 pandemic.

This integrative review has brought the findings of 8 articles, on ethical challenges of nurses during the COVID-19 pandemic, in three thematic areas. The ethical challenges were classified as nurses' safety, role and moral distress, resource allocation, and the nurse-client relationship.

In this time of COVID-19 pandemic, nurses were not fully protected by personal protective equipment. Because of the contagious nature of the virus, failure in any personal protection does not only affect the nurses who are in charge but also clients being served by them. On top of this, they were subjected to work beyond their job description and duty that could induce moral distress. ${ }^{7,9,12}$ These incidences could lower the quality of care, and harm the clients and surrounding communities, which antagonizes one of the basic principles of bioethics, non-maleficence. Non-maleficence refers to the bioethical principles that any type of care harms neither the patient nor others in society. $^{7}$

Another tangible ethical challenge for nurses during the pandemic was fair allocation of medical resources. The distribution of scarce resources and competing needs is a basic nursing ethical principle, justice, in the context of medical ethics that implies fairness in medical decisions. ${ }^{16}$ But, in reality, during the COVID-19 pandemic, nurses were making blurred decisions on various issues, such aswhich patients are most likely to get into a scarce intensive care unit bed and mechanical ventilation, or extracorporeal membrane oxygenation., ${ }^{4,8-11,13}$ In the middle of the pandemic, we were observing that COVID-19 patients lying on the floor and waiting for medical care and/or with substandard level of care because they were beyond the capacity of hospital resources.

Lastly, the tradition of nurse-client interaction was negatively impacted by the COVID-19 pandemic. Nurses are the ones who support patients to have an even peaceful dying process and bereavement. On the contrary, many people were dying in isolation and ICU separated from their families and beloved others, even without getting the opportunities to have end-of-life-conversations. ${ }^{8,9}$ A patient would have the autonomy to decide who should be involved in taking care of him/her during a stay in the hospital. However, nurses were not capable of fulfilling patients' will and wishes, which is against the biomedical ethical principle of autonomy. The overall consequences of such gaps have left a scar on the history of the modern nursing profession.

\section{Limitation}

Limited research articles are available related to the ethical challenges of nurses in COVID-19 pandemic. Also, studies discussing under more general titles, such as healthcare professionals, providers, caregivers, and the like, were not included in this review. 


\section{Conclusion}

Nurses have continued to experience the ethical challenges of COVID-19 pandemic. Primarily, the lack of full protection of nurses across the health industry has raised ethical questions such as the extent of their duty, scarce resources, and the failure of personal protective equipment. Second, a significant number of nurses were also facing moral distress because they were under prolonged pressure to keep up the resources needed to provide safe and highquality nursing care. Furthermore, nurses were also challenged to restrict many COVID-19 patients from having end-of-life communication with their families.

\section{Disclosure}

The authors declare that they have no competing interests.

\section{References}

1. Nyashanu M, Pfende F, Ekpenyong M. Exploring the challenges faced by frontline workers in health and social care amid the COVID-19 pandemic: experiences of frontline workers in the English Midlands region, UK. J Interprof Care. 2020;34(5):655-661. doi:10.1080/ 13561820.2020.1792425

2. Dudzinski DM, Hoisington BY, Brown CE. Ethics Lessons From Seattle's Early Experience With COVID-19. Am J Bioeth. 2020;20 (7):67-74. doi:10.1080/15265161.2020.1764137

3. Shah A, Aacharya RP. Combating COVID-19 Pandemic in Nepal: ethical Challenges in an Outbreak. JNMA J Nepal Med Assoc. 2020;58(224):276-279. doi:10.31729/jnma.4959

4. Turale S, Meechamnan C, Kunaviktikul W. Challenging times: ethics, nursing and the COVID-19 pandemic. Int Nurs Rev. 2020;67 (2):164-167. doi:10.1111/inr. 12598

5. Whittemore R, Knafl K. The integrative review: updated methodology. $J$ Adv Nurs. 2005;52(5):546-553. doi:10.1111/j.1365-2648.2005.03 621.x
6. Moher D, Liberati A, Tetzlaff J, Altman DG, The PRISMA Group (2009). Preferred Reporting Items for Systematic Reviews and MetaAnalysesThe PRISMA Statement. PLoS Med: 6(7): e1000097.

7. Zhu J, Stone T, Petrini M. The ethics of refusing to care for patients during the coronavirus pandemic: a Chinese perspective. Nurs Inq. 2020;28(1):e12380. doi:10.1111/nin.12380

8. Nasser I, Abu-El-Noor M, Khalil A-E-N. Ethical issues in caring for COVID-patients: a view from Gaza. Nurs Ethics. 2020;27(8). doi:10.1177/0969733020956733

9. Morley G, Grady C, McCarthy J, Ulrich CM. Covid-19: ethical Challenges for Nurses. Hastings Cent Rep. 2020;50(3):35-39. doi:10.1002/hast.1110

10. McKenna H. Covid-19: ethical issues for nurses. Int J Nurs Stud. 2020;110:103673. doi:10.1016/j.ijnurstu.2020.103673

11. Sperling D. Ethical dilemmas, perceived risk, and motivation among nurses during the COVID-19 pandemic. Nurs Ethics. 2020;28 (1):969733020956376. doi:10.1177/0969733020956376

12. Jia Y, Chen O, Xiao Z, Xiao J, Bian J, Jia H. Nurses' ethical challenges caring for people with COVID-19: a qualitative study. Nurs Ethics. 2020;28(1):969733020944453. doi:10.1177/096973302 0944453

13. Combe LG. Reopening Schools During COVID-19: school Nurse Ethical Conflicts and Moral Dilemmas. NASN Sch Nurse. 2020;35 (6):308-312. doi:10.1177/1942602X20963522

14. Robert R, Kentish-Barnes N, Boyer A, Laurent A, Azoulay E, Reignier J. Ethical dilemmas due to the Covid-19 pandemic. Ann Intensive Care. 2020;10(1). doi:10.1186/s13613-020-00702-7

15. Druml C. COVID-19 and ethical preparedness? Wien Klin Wochenschr. 2020;132(13紼14):400-402. doi:10.1007/s00508-02001709-7

16. Principles of Biomedical Ethics - Tom L. Beauchamp, Professor of Philosophy and Senior Research Scholar Tom L Beauchamp, James F. Childress, University Professor and Hollingsworth Professor of Ethics James F Childress - Google Books. Available from: https:// books.google.es/books?hl=en\&id= $14 \mathrm{H} 7 \mathrm{MOw} 1 \mathrm{o} 4 \mathrm{C} \&$ oi $=$ fnd $\& \mathrm{pg}=$ PR9\&dq=Beauchamp, + T. + I., $+\% 26+$ Childress, + J. + F. $+(2001)$. + Principles + of + biomedical+ethics $+(5$ th + ed. $) .+$ Oxford, + UK: + Oxford + University+Press.\&ots=1xS10JDi-r\&sig=m3IvFhcGy0RQt TDxwna7n9GB7U\&redir_esc $=\mathrm{y} \# \mathrm{v}=$ onepage $\& \mathrm{q} \& \mathrm{f}=$ false. $\quad$ Accessed March 20, 2021.
Journal of Multidisciplinary Healthcare

\section{Publish your work in this journal}

The Journal of Multidisciplinary Healthcare is an international, peerreviewed open-access journal that aims to represent and publish research in healthcare areas delivered by practitioners of different disciplines. This includes studies and reviews conducted by multidisciplinary teams as well as research which evaluates the results or conduct of such teams or healthcare processes in general. The journal covers a very wide range of areas and welcomes submissions from practitioners at all levels, from all over the world. The manuscript management system is completely online and includes a very quick and fair peer-review system. Visit http://www.dovepress.com/testimonials. php to read real quotes from published authors. 